\title{
Application of Compost and Vermicompost as Substitutes for Mineral Fertilizers to Produce Green Beans
}

\author{
S. Abou El-Hassan", Mona Abd Elwanis ${ }^{* * *}$ and M. Z. El-Shinawy ${ }^{* * *}$ \\ *Central Laboratory of Organic Agriculture, Agricultural Research Center, \\ **Protected Agriculture Department, Horticulture Research Institute, Agricultural \\ Research Center and ***Horticulture Department, Faculty of Agriculture, Ain Shams \\ University, Egypt.
}

\begin{abstract}
QUSTAINABLE agricultural development need to provide alternatives of mineral fertilizers to produce safe food for humans, maintain of soil fertility and preserve of environment from pollution. Field experiment was conducted at the site of Vegetable Research Departments, Horticulture Research Institutein Giza Governorate, Egypt, to study possibility of using compost and vermicompost (compost of earthworm) as substitutes partial or fully for mineral fertilizers used in the production of green beans. The bean seeds (cv. Paulista) were sown in clay soil during the summer season of 2016 and 2017. Treatments of compost and vermicompost individually or in combination with or without adding $50 \%$ of recommended dose of mineral fertilizers, were investigated on bean plants. The effects of these treatments on the growth and yield of green beans were compared to full recommended dose of mineral fertilizers as control. All treatments of compost and vermicompost without mineral fertilizers decreased all the vegetative properties of bean plants. Compost and vermicompost singly or in combination $+50 \%$ mineral fertilizers were not showed any significant differences compared to $100 \%$ mineral fertilizers. The treatments of $100 \%$ mineral fertilizers and $50 \%$ mineral fertilizers + vermicompost sole or combined with compost gave the highest early and total yield compared to other treatments. Applying compost and vermicompost with or without mineral fertilizers, decreased nitrate content of bean pods. This study suggested possibility for using compost and vermicompost to reduce the amount of mineral fertilizers to produce good yield, healthy and safe of green beans.
\end{abstract}

Keywords: Snap bean, Compost, Vermicompost, Organic, Mineral fertilizers.

\section{Introduction}

Beans (Phaseolus vulgaris L.) are one of the most important leguminous crops in the Egyptian consumer. Beans are grown for local marketing or export, whether for green pods consumption, called snap beans or dry seed consumption, called common beans. The cultivated area of snap beans in Egypt is about 59313 feddans (feddan $=0.4$ hectare), produced about 249396 tons (Ministry of Agriculture and Land Reclamation, 2015).

The excessive use of chemical fertilizers in agriculture is an issue of concern. It causes, high level the pollutants in fruits, decrease soil fertility and pollution of groundwater (Hernandez et al., 2010). Organic fertilizers can be used to reduce the amount of toxic compounds (such as nitrate) produced by mineral fertilizers, improving the quality of vegetables produced as well as human health (Abd El-Hamied, 2001 and Mahmoud et al., 2009).

Substitution of chemical fertilizers by the organic amendments is very important for sustainability of agriculture production and maintain of soil fertility (Parakash and Prasad, 2000). The compost and vermicompost quality is the most essential criterion in recycling organic waste and utilization in agriculture as organic amendments, they can meet the nutrient requirements of agriculture crops and significantly reduce the use of chemical fertilizers (Kowalchuk et al., 1999 and Mavaddati et al., 2010).

Compost is an aerobically decomposed organic material derived from plants and animal sources by mesophilic and thermophilic microorganisms (Martens, 2000 and Insam \& de Bertoldi, 2007). Vermicompost is product of organic 
matter degradation through interactions between earthworms and microorganisms (Edwards \& Bater, 1992 and Arancon et al., 2008). In this process, earthworms fragment the waste, enhance microbial activity and accelerate rates of decomposition, as in composting, but by non-thermophilic process. When the materials pass through the worm body, impregnate with gastrointestinal mucosa, vitamins and enzymes (Inbar et al., 1993, Mavaddati et al., 2010 and Abduli et al., 2013).

Compost and vermicompost are not only the sources of organic matter and nutrient, but also boost microbial population, physical, biological and chemical properties of the soil (Albiach et al., 2000 and Baziramakenga \& Simard, 2001). Among organic fertilizers, compost and vermicompost are sources of plant nutrients and produce vigorous plants (Manivannan et al., 2009 and Shehata \& El-Helaly, 2010). Compost and vermicompost are soil conditioners that provide nutrients and organic matter within the soil, improve the water and nutrient holding of soil (Giusquiani et al., 1995, Wells et al., 2000 and Cespedes Leon et al., 2006). Application of compost to newly reclaimed lands has a positive effect on green bean growth and production
(Abdel-Mawgoud, 2006). Vermicompost has a significant positive influence on plant growth, flowering, fruiting, root development, yield and quality of beans (Fernandez-Luqueno et al.,2010 and Singh et al., 2011). This study aims to evaluate replacing the mineral fertilizers for producing green beans partly or totally using compost and vermicompost.

\section{Materials and Methods}

The field experiments were carried out at the site of Vegetable Research Departments, Horticulture Research Institute, Agricultural Research Center, Dokki district in Giza Governorate, Egypt, during two successive seasons of 2016 and 2017.

\section{Plant Material}

Seeds of snap bean (cv. Paulista) were sown in the field on 10 and 14 of February in the first and second seasons, respectively.

\section{Soil Properties}

The experimentwas conducted in clay soil using drip irrigation system. The chemical and physical properties of the soil are shown in Table1.

TABLE 1. Analyses of the experimental soil.

\begin{tabular}{|c|c|c|c|c|c|c|c|c|c|c|c|c|c|}
\hline \multirow{2}{*}{$\begin{array}{c}\text { Clay } \\
\%\end{array}$} & \multirow{2}{*}{$\begin{array}{l}\text { Silt } \\
\%\end{array}$} & \multirow{2}{*}{$\begin{array}{c}\text { Sand } \\
\%\end{array}$} & \multirow{2}{*}{ Texture } & \multirow{2}{*}{$\begin{array}{c}\text { pH } \\
1: 2.5\end{array}$} & \multirow{2}{*}{$\begin{array}{c}\text { EC1:10 } \\
\mathrm{dS} / \mathrm{m}\end{array}$} & \multicolumn{4}{|c|}{ Cationsmeq/l } & \multicolumn{4}{|c|}{ Anions meq/l } \\
\hline & & & & & & $\mathrm{Ca}^{++}$ & $\mathbf{M g}^{++}$ & $\mathrm{Na}^{+}$ & $\mathbf{K}^{+}$ & $\mathrm{Co}_{3}^{-}$ & $\mathrm{HCO}_{3}^{-}$ & $\mathrm{Cl}^{-}$ & $\mathrm{SO}_{4}=$ \\
\hline 48.40 & 42.30 & 9.30 & $\begin{array}{l}\text { Silty } \\
\text { clay }\end{array}$ & 8.25 & 1.45 & 2.80 & 1.55 & 1.14 & 1.18 & 2.44 & 1.25 & 1.40 & 1.58 \\
\hline
\end{tabular}

The Experimental Layout

The experiment was divided into ridges (70 $\mathrm{cm}$ width). The seeds were sown at a distance of $15 \mathrm{~cm}$ in two rows on the ridge, two seeds in each placement.

\section{The Experimental Treatments}

- $100 \%$ of recommended NPK of mineral fertilizers (MF) as a control

- $100 \%$ compost (C) as recommended $\mathrm{N}$

- $100 \%$ vermicompost (V) as recommended $\mathrm{N}$

- $50 \% \mathrm{C}+50 \% \mathrm{~V}$

- $50 \% \mathrm{MF}+50 \% \mathrm{C}$

- $50 \% \mathrm{MF}+50 \% \mathrm{~V}$

- $50 \% \mathrm{MF}+25 \% \mathrm{C}+25 \% \mathrm{~V}$

\section{Experimental Design}

The experimental treatments were arranged in complete randomized blocks design with three replicates. The plot area was $4.2 \mathrm{~m}^{2}$ (6 m length and $0.7 \mathrm{~m}$ width).

Egypt. J. Hort. Vol. 44, No.2 (2017)

\section{Quantities of application}

The mineral fertilizers of NPK were applied according to Ministry of Agriculture and Land Reclamation (2013) as follow 60kg N/fed. as 179 $\mathrm{kg}$ ammonium nitrate $(33.5 \% \mathrm{~N}), 30 \mathrm{~kg} \mathrm{P}_{2} \mathrm{O}_{5} /$ fed. as $194 \mathrm{~kg}$ calcium super phosphate $\left(15.5 \% \mathrm{P}_{2} \mathrm{O}_{5}\right)$ and $48 \mathrm{~kg} \mathrm{~K}_{2} \mathrm{O} /$ fed. as $100 \mathrm{~kg}$ potassium sulphate $\left(\begin{array}{lll}48 \% & \mathrm{~K}_{2} \mathrm{O}\end{array}\right)$. The quantities of compost and vermicompost were calculated based on nitrogen recommended dose in clay soil $(60 \mathrm{~kg} / \mathrm{fed}$.), that were 6.316 and 4.880 tons/feddan on respectively. Analyses of the used compost and vermicompost are showed in Table 2.

\section{Time and Method of application}

Calcium super phosphate was added as one dose during soil preparation, whereas ammonium nitrate and potassium sulphate were added at three equal portions, during soil preparation, after 20 and 40 days from sowing. Two-thirds of the quantity of both compost and vermicompost were 
added in solid form during soil preparation, while the other third was added as extract $(1: 10 \mathrm{v}: \mathrm{v})$ to the soil beside plants every two weeks at rate $1 \mathrm{~L} /$ $\mathrm{m}^{2}$ (Abou-El-Hassanet al., 2014).

TABLE 2. Analyses of the compost and vermicompost.

\begin{tabular}{cccccccccccccccc}
\hline Type & $\begin{array}{c}\mathbf{p H} \\
\mathbf{1 : 5}\end{array}$ & $\begin{array}{c}\text { EC 1:10 } \\
\mathbf{d S} / \mathbf{m}\end{array}$ & $\begin{array}{c}\mathbf{O} \text { (\%) } \\
(\mathbf{\%})\end{array}$ & $\mathbf{N}$ & $\mathbf{P}$ & $\mathbf{K}$ & $\mathbf{C a}$ & $\mathbf{M g}$ & $\mathbf{F e}$ & $\mathbf{Z n}$ & $\mathbf{M n}$ & $\mathbf{C u}$ \\
\hline Compost & 7.53 & 2.67 & 27.13 & 0.95 & 0.37 & 0.74 & 0.36 & 0.67 & 644 & 98 & 203 & 11 \\
Vermicompost & 8.33 & 5.09 & 20.60 & 1.23 & 0.67 & 0.94 & 0.47 & 0.64 & 567 & 88 & 205 & 13 \\
\hline
\end{tabular}

\section{Data Recorded}

\section{Growth and nutritional status}

In the beginning of fruit set stage, three plants were randomly chosen from each plot to determine plant height, leaf number and fresh shoot weight of plant. Also, chlorophyll reading was measured in the third upper leaf by using Minolta Chlorophyll Meter Spad 501. Nutrient content (NPK) in bean plants were determined in dry matter of the third upper leaf according to Cottenie et al. (1982). Total nitrogen was determined by Kjeldahl method according to the procedure described by FAO (1989). Phosphorus content was determined using spectrophotometer according to FAO (1989). Potassium content was determined photometrically using Flame photometer as described by Chapman and Pratt (1961).

\section{Yield and quality characters}

After 60 days from sowing, the pods were harvestedweekly for four times. Early yield was recorded during the first two harvests. Total yield was recorded per plot after each harvesting accumulatively until the end of harvesting season. Five plants from each replicate were randomly chosen to measure weight and number of pods per plant. Ten pods from each replicate were randomly chosen to determine length, diameter, weight and dry matter percent of pod. Total soluble solids (TSS) were measured by using Digital Refractometer. Percentage of fiber and protein were determined according to AOAC (2005). As well as, nitrate contentof pods was determined using Cardy Nitrate Meter Model HORIBA, Spectrum Technologies, Inc., as described by AlMoshileh et al. (2004).

\section{Statistical analysis}

Data of the two seasons were arranged and statistically analyzed by the analysis of variances according to Snedecor and Cochran (1980) with SAS software, version 9. Comparison of treatment means was donebyTukey test at significance level 0.05 .

\section{$\underline{\text { Results and Discussion }}$}

The effect of treatments on vegetative properties of bean plants present in Table 3 . Data showed that all applications of compost and vermicompost without mineral fertilizers decreased all the vegetative properties (height, leaf number, chlorophyll reading and fresh shoot weight) of bean plants compared to $100 \%$ mineral fertilizers in both seasons. The lowest values of vegetative growth parameters were resulted from $100 \%$ compost treatment. While all treatments of organic fertilizers (compost and vermicompost singly or combined) $+50 \%$ mineral fertilizers were not showed any significant differences compared to $100 \%$ mineral fertilizers. The maximum growth obtained by mineral fertilizer may be due to high composition of nitrogen available in mineral fertilizer, which supplement to the plant's vegetative phase. The result was in harmony with the findings of Sharma et al. (2003) and Deshmukh et al. (2005). On another hand, low values in the parameters of vegetative growth with applying organic fertilizers only might be due to its slow release, thus the nutrients available of them are not sufficient for the plant requirements and this let to reduce vegetative growth of plant as was mentioned by Abdel-Mawgoud (2006) and Abou-El-Hassan et al. (2014).

The effect of treatments on the nutritional statusinbean plantsshow in Table 4. The highest concentrations of $\mathrm{N}$ and $\mathrm{K}$ were preceded by $100 \%$ mineral fertilizers treatment followed by $50 \%$ mineral fertilizers + compost and vermicompost in dividual or in combination. On the other hand,the lowest concentrations of $\mathrm{N}$ and $\mathrm{K}$ were obtained by compost without mineral fertilizers treatment. No significant differences were detected on $\mathrm{P}$ content of leaves among all treatments except compost without mineral fertilizers treatment, which decreased the concentration of $\mathrm{P}$ in the leaves. The high content of $\mathrm{N}$ and $\mathrm{K}$ in bean leaves 
with treatment of mineral fertilizer only might be due to it is easy decomposition, so the plants absorb nutrients from it in large quantities. These results are in agreement with those obtained by Sharma et al. (2003), Singh \& Chauhan (2009) and Mitova \& Stancheva (2013).

TABLE 3. Effect of treatments on vegetative growth of bean plants during 2016 and 2017 seasons.

\begin{tabular}{|c|c|c|c|c|c|c|c|c|}
\hline \multirow[t]{2}{*}{ Treatments } & \multicolumn{2}{|c|}{$\begin{array}{c}\text { Plant height } \\
\mathrm{cm} \\
\end{array}$} & \multicolumn{2}{|c|}{ Leaf No } & \multicolumn{2}{|c|}{$\begin{array}{c}\text { Chlorophyll } \\
\text { SPAD } \\
\end{array}$} & \multicolumn{2}{|c|}{$\begin{array}{c}\text { FSW } \\
\text { g / plant }\end{array}$} \\
\hline & \multicolumn{8}{|c|}{ First season } \\
\hline $100 \% \mathrm{MF}$ & 68.00 & $\mathrm{a}$ & 17.00 & $\mathrm{a}$ & 33.27 & $\mathrm{a}$ & 83.33 & $\mathrm{a}$ \\
\hline $100 \% \mathrm{C}$ & 42.00 & $\mathrm{c}$ & 11.00 & $\mathrm{c}$ & 28.70 & $\mathrm{~b}$ & 53.33 & $\mathrm{c}$ \\
\hline $100 \% \mathrm{~V}$ & 51.33 & $\mathrm{~b}$ & 13.00 & $\mathrm{~b}$ & 29.30 & $\mathrm{~b}$ & 66.67 & bc \\
\hline $50 \% \mathrm{MF}+50 \% \mathrm{C}$ & 63.33 & $\mathrm{a}$ & 15.33 & $\mathrm{a}$ & 30.67 & $a b$ & 73.33 & $a b$ \\
\hline $50 \% \mathrm{MF}+50 \% \mathrm{~V}$ & 66.00 & $\mathrm{a}$ & 16.67 & $\mathrm{a}$ & 32.33 & $\mathrm{a}$ & 81.67 & $\mathrm{a}$ \\
\hline \multirow[t]{2}{*}{$50 \% \mathrm{MF}+25 \% \mathrm{C}+25 \% \mathrm{~V}$} & 64.67 & $\mathrm{a}$ & 15.67 & $\mathrm{a}$ & 30.47 & $\mathrm{ab}$ & 75.67 & $\mathrm{ab}$ \\
\hline & \multicolumn{8}{|c|}{ Second season } \\
\hline $100 \% \mathrm{MF}$ & 58.85 & $\mathrm{a}$ & 14.67 & $\mathrm{a}$ & 36.33 & $\mathrm{a}$ & 70.67 & $\mathrm{a}$ \\
\hline $50 \% \mathrm{MF}+50 \% \mathrm{C}$ & 54.67 & $\mathrm{a}$ & 12.33 & $\mathrm{bc}$ & 34.17 & $\mathrm{ab}$ & 62.00 & $a b c$ \\
\hline $50 \% \mathrm{MF}+50 \% \mathrm{~V}$ & 58.11 & $\mathrm{a}$ & 14.33 & $\mathrm{a}$ & 35.40 & $\mathrm{a}$ & 68.27 & $\mathrm{a}$ \\
\hline $50 \% \mathrm{MF}+25 \% \mathrm{C}+25 \% \mathrm{~V}$ & 55.71 & $\mathrm{a}$ & 13.67 & $a b$ & 34.23 & $a b$ & 65.50 & $a b$ \\
\hline
\end{tabular}

Means followed in same column by similar letters are not statistically different at 0.05 level according to Tukey test.

$\mathrm{FSW}=$ fresh shoot weight $\quad \mathrm{MF}=$ mineral fertilizer

$\mathrm{C}=$ compost $\quad \mathrm{V}=$ vermicompost

TABLE 4. Effect of treatments on NPK contentof bean plants during 2016 and 2017 seasons.

\begin{tabular}{|c|c|c|c|c|c|c|}
\hline \multirow{2}{*}{ Treatments } & \multicolumn{2}{|c|}{$\begin{array}{l}\mathbf{N} \\
\%\end{array}$} & \multicolumn{2}{|c|}{$\begin{array}{c}\mathbf{P} \\
\%\end{array}$} & \multicolumn{2}{|c|}{$\begin{array}{l}\mathbf{K} \\
\%\end{array}$} \\
\hline & \multicolumn{6}{|c|}{ First season } \\
\hline $100 \% \mathrm{MF}$ & 5.02 & $\mathrm{a}$ & 0.390 & $\mathrm{ab}$ & 3.71 & $\mathrm{a}$ \\
\hline $100 \% \mathrm{C}$ & 3.42 & e & 0.387 & $\mathrm{~b}$ & 2.26 & d \\
\hline $100 \% \mathrm{~V}$ & 4.11 & $\mathrm{~d}$ & 0.410 & $\mathrm{ab}$ & 2.78 & $\mathrm{c}$ \\
\hline $50 \% \mathrm{C}+50 \% \mathrm{~V}$ & 3.62 & e & 0.403 & $\mathrm{ab}$ & 2.58 & $\mathrm{c}$ \\
\hline $50 \% \mathrm{MF}+50 \% \mathrm{C}$ & 4.39 & $\mathrm{c}$ & 0.390 & $\mathrm{ab}$ & 3.22 & $b$ \\
\hline $50 \% \mathrm{MF}+50 \% \mathrm{~V}$ & 4.77 & $\mathrm{~b}$ & 0.437 & a & 3.44 & $\mathrm{~b}$ \\
\hline \multirow[t]{2}{*}{$50 \% \mathrm{MF}+25 \% \mathrm{C}+25 \% \mathrm{~V}$} & 4.62 & $\mathrm{~b}$ & 0.430 & $\mathrm{ab}$ & 3.27 & $\mathrm{~b}$ \\
\hline & \multicolumn{6}{|c|}{ Second season } \\
\hline $100 \% \mathrm{MF}$ & 5.28 & $\mathrm{a}$ & 0.426 & $\mathrm{ab}$ & 3.86 & $\mathrm{a}$ \\
\hline $100 \% \mathrm{C}$ & 3.55 & $\mathrm{e}$ & 0.405 & $\mathrm{~b}$ & 2.45 & d \\
\hline $100 \% \mathrm{~V}$ & 4.22 & d & 0.429 & $a b$ & 2.99 & $\mathrm{c}$ \\
\hline $50 \% \mathrm{C}+50 \% \mathrm{~V}$ & 3.76 & $\mathrm{e}$ & 0.418 & $a b$ & 2.76 & $\mathrm{c}$ \\
\hline $50 \% \mathrm{MF}+50 \% \mathrm{C}$ & 4.54 & $\mathrm{c}$ & 0.422 & $a b$ & 3.44 & $\mathrm{~b}$ \\
\hline $50 \% \mathrm{MF}+50 \% \mathrm{~V}$ & 4.94 & $\mathrm{~b}$ & 0.452 & $\mathrm{a}$ & 3.61 & $\mathrm{~b}$ \\
\hline $50 \% \mathrm{MF}+25 \% \mathrm{C}+25 \% \mathrm{~V}$ & 4.74 & $\mathrm{bc}$ & 0.449 & $\mathrm{a}$ & 3.46 & $\mathrm{~b}$ \\
\hline
\end{tabular}

Means followed in same column by similar letters are not statistically different at 0.05 level according to Tukey test.

$\mathrm{MF}=$ mineral fertilizer $\quad \mathrm{C}=$ compost

The effect of different treatments on yieldpresent in Table 5. Data showed that the treatments of $100 \%$ mineral fertilizers, $50 \%$ mineral fertilizers + vermicompost sole or combined with compost gave the highest early and total yield compared to other treatments. The treatments of $50 \%$ mineral fertilizers +

Egypt. J. Hort. Vol. 44, No.2 (2017) compostand vermicompost without mineral fertilizers came in the second order of yield. The lowest early and total yield was obtained by compost without mineral fertilizers treatment in the two seasons. This trend was true with number of pods on plant. The effect of treatments on properties of snap bean pods show in Table 6 . 
The results indicated that all treatments of organic fertilizers without mineral fertilizers decreased length and weight of pod in both seasons. No significant differences were detected on pod diameter among all treatments except compost only treatment which decreased pod diameter compared to other treatments. All treatments of organic fertilizers $+50 \%$ mineral fertilizers gave similar results to $100 \%$ mineral fertilizers of length, diameter and weight of pod with no significant differences among them. These findings are agreement with those obtained by Singh \& Chauhan (2009), Fernandez-Luqueno et al. (2010), Singh et al. (2011), Kadam \& Pathade (2014) and Alhrout et al. (2016) on bean.

TABLE 5. Effect of treatments on yield components of green beans during 2016 and 2017 seasons.

\begin{tabular}{|c|c|c|c|c|c|c|c|c|}
\hline \multirow[t]{2}{*}{ Treatments } & \multicolumn{2}{|c|}{$\begin{array}{c}\text { Early yield } \\
\mathrm{kg} / \mathrm{m}^{2}\end{array}$} & \multicolumn{2}{|c|}{$\begin{array}{c}\text { Total yield } \\
\mathrm{kg} / \mathrm{m}^{2}\end{array}$} & \multicolumn{2}{|c|}{$\begin{array}{c}\text { Yield/plant } \\
\text { g }\end{array}$} & \multicolumn{2}{|c|}{ Pod No/plant } \\
\hline & \multicolumn{8}{|c|}{ First season } \\
\hline $100 \% \mathrm{MF}$ & 0.44 & $\mathrm{a}$ & 1.43 & $\mathrm{a}$ & 54.63 & $\mathrm{a}$ & 12.33 & $\mathrm{a}$ \\
\hline $100 \% \mathrm{C}$ & 0.07 & e & 0.76 & $\mathrm{c}$ & 29.51 & d & 8.33 & d \\
\hline $100 \% \mathrm{~V}$ & 0.26 & $\mathrm{~cd}$ & 1.07 & $\mathrm{~b}$ & 41.67 & $\mathrm{c}$ & 10.33 & $\mathrm{bc}$ \\
\hline $50 \% \mathrm{C}+50 \% \mathrm{~V}$ & 0.22 & $\mathrm{~d}$ & 0.82 & $\mathrm{c}$ & 31.50 & d & 9.17 & $\mathrm{~cd}$ \\
\hline $50 \% \mathrm{MF}+50 \% \mathrm{C}$ & 0.33 & $\mathrm{bc}$ & 1.20 & $\mathrm{~b}$ & 45.33 & $\mathrm{bc}$ & 10.83 & $\mathrm{~b}$ \\
\hline $50 \% \mathrm{MF}+50 \% \mathrm{~V}$ & 0.40 & $\mathrm{ab}$ & 1.39 & $\mathrm{a}$ & 53.40 & $\mathrm{a}$ & 12.27 & $\mathrm{a}$ \\
\hline \multirow[t]{2}{*}{$50 \% \mathrm{MF}+25 \% \mathrm{C}+25 \% \mathrm{~V}$} & 0.39 & $\mathrm{ab}$ & 1.36 & $\mathrm{a}$ & 49.67 & $a b$ & 11.50 & $\mathrm{ab}$ \\
\hline & \multicolumn{8}{|c|}{ Second season } \\
\hline $100 \% \mathrm{MF}$ & 0.51 & $\mathrm{a}$ & 1.24 & $\mathrm{a}$ & 46.69 & $\mathrm{a}$ & 11.26 & $\mathrm{a}$ \\
\hline $100 \% \mathrm{C}$ & 0.20 & $\mathrm{~d}$ & 0.74 & d & 29.59 & e & 8.38 & $\mathrm{~d}$ \\
\hline $100 \% \mathrm{~V}$ & 0.30 & $\mathrm{~cd}$ & 0.97 & $\mathrm{bc}$ & 35.77 & $\mathrm{~cd}$ & 9.62 & $\mathrm{c}$ \\
\hline $50 \% \mathrm{C}+50 \% \mathrm{~V}$ & 0.27 & $\mathrm{~cd}$ & 0.85 & $\mathrm{~cd}$ & 34.36 & de & 10.00 & bc \\
\hline $50 \% \mathrm{MF}+50 \% \mathrm{C}$ & 0.38 & $\mathrm{bc}$ & 1.08 & $a b$ & 40.33 & $\mathrm{bc}$ & 10.61 & $a b c$ \\
\hline $50 \% \mathrm{MF}+50 \% \mathrm{~V}$ & 0.48 & $\mathrm{a}$ & 1.22 & $\mathrm{a}$ & 45.95 & $\mathrm{a}$ & 11.11 & $\mathrm{ab}$ \\
\hline $50 \% \mathrm{MF}+25 \% \mathrm{C}+25 \% \mathrm{~V}$ & 0.45 & $\mathrm{a}$ & 1.17 & $a b$ & 43.35 & $a b$ & 10.96 & $a b$ \\
\hline
\end{tabular}

Means followed in same column by similar letters are not statistically different at 0.05 level according to Tukey test.

$\mathrm{MF}=$ mineral fertilizer $\quad \mathrm{C}=$ compost $\quad \mathrm{V}=$ vermicompost

TABLE 6. Effect of treatments on properties of green bean pods during 2016 and 2017 seasons.

\begin{tabular}{|c|c|c|c|c|c|c|c|c|}
\hline \multirow[t]{2}{*}{ Treatments } & \multicolumn{2}{|c|}{$\begin{array}{c}\text { Pod length } \\
\mathrm{cm}\end{array}$} & \multicolumn{2}{|c|}{$\begin{array}{c}\text { Pod diameter } \\
\text { mm }\end{array}$} & \multicolumn{2}{|c|}{$\begin{array}{c}\text { Pod fresh weight } \\
\text { (g) }\end{array}$} & \multicolumn{2}{|c|}{$\begin{array}{c}\text { Pod dry weight } \\
\text { (g) }\end{array}$} \\
\hline & \multicolumn{8}{|c|}{ First season } \\
\hline $100 \% \mathrm{MF}$ & 15.33 & $\mathrm{a}$ & 7.33 & $\mathrm{a}$ & 4.71 & $\mathrm{a}$ & 0.357 & $\mathrm{a}$ \\
\hline $100 \% \mathrm{C}$ & 13.60 & $\mathrm{~b}$ & 6.00 & $\mathrm{~b}$ & 3.63 & $\mathrm{~d}$ & 0.257 & $\mathrm{~d}$ \\
\hline $100 \% \mathrm{~V}$ & 13.67 & $\mathrm{~b}$ & 6.50 & $a b$ & 3.96 & $\mathrm{~cd}$ & 0.297 & bed \\
\hline $50 \% \mathrm{C}+50 \% \mathrm{~V}$ & 13.67 & $\mathrm{~b}$ & 6.67 & $a b$ & 3.66 & $\mathrm{~d}$ & 0.277 & $\mathrm{~cd}$ \\
\hline $50 \% \mathrm{MF}+50 \% \mathrm{C}$ & 14.50 & $a b$ & 7.00 & $\mathrm{ab}$ & 4.19 & $\mathrm{bc}$ & 0.317 & $a b c$ \\
\hline $50 \% \mathrm{MF}+50 \% \mathrm{~V}$ & 15.33 & $\mathrm{a}$ & 7.33 & $\mathrm{a}$ & 4.49 & $a b$ & 0.337 & $a b$ \\
\hline \multirow[t]{2}{*}{$50 \% \mathrm{MF}+25 \% \mathrm{C}+25 \% \mathrm{~V}$} & 15.00 & $a b$ & 7.17 & $\mathrm{a}$ & 4.28 & $\mathrm{bc}$ & 0.320 & $a b$ \\
\hline & \multicolumn{8}{|c|}{ Second season } \\
\hline $100 \% \mathrm{MF}$ & 13.67 & $\mathrm{a}$ & 6.99 & $\mathrm{a}$ & 4.37 & $\mathrm{a}$ & 0.354 & $\mathrm{a}$ \\
\hline $100 \% \mathrm{C}$ & 11.67 & $\mathrm{c}$ & 5.67 & $\mathrm{~b}$ & 3.38 & $\mathrm{c}$ & 0.266 & $\mathrm{~d}$ \\
\hline $100 \% \mathrm{~V}$ & 12.00 & $\mathrm{bc}$ & 6.27 & $a b$ & 3.58 & $\mathrm{bc}$ & 0.285 & $\mathrm{~cd}$ \\
\hline $50 \% \mathrm{C}+50 \% \mathrm{~V}$ & 12.33 & $a b c$ & 6.37 & $\mathrm{ab}$ & 3.72 & $\mathrm{bc}$ & 0.304 & $\mathrm{bc}$ \\
\hline $50 \% \mathrm{MF}+50 \% \mathrm{C}$ & 13.33 & $a b$ & 7.00 & $\mathrm{a}$ & 4.24 & $\mathrm{a}$ & 0.344 & $\mathrm{a}$ \\
\hline $50 \% \mathrm{MF}+50 \% \mathrm{~V}$ & 11.67 & $\mathrm{c}$ & 6.17 & $\mathrm{ab}$ & 3.50 & $\mathrm{c}$ & 0.280 & $\mathrm{~cd}$ \\
\hline $50 \% \mathrm{MF}+25 \% \mathrm{C}+25 \% \mathrm{~V}$ & 13.00 & $\mathrm{abc}$ & 6.57 & $\mathrm{ab}$ & 4.05 & $\mathrm{ab}$ & 0.323 & $\mathrm{ab}$ \\
\hline
\end{tabular}

Means followed in same column by similar letters are not statistically different at 0.05 level according to Tukey test. $\begin{array}{lll}\mathrm{MF}=\text { mineral fertilizer } & \mathrm{C}=\text { compost } & \mathrm{V}=\text { vermicompost }\end{array}$

Overall, all treatments of compost and vermicompost without mineral fertilizers reduced yield and properties of snap bean pods. This reduction may be due to organic fertilizers are slow release fertilizers, which leads to the nutrients available from them are insufficient for the plant requirements and thus reduce the vegetable growth, which reflected on reducing 
yield of beans. While the combination of mineral and organic fertilizers, could improve yield and its components compared to organic fertilizers only. This may be attributing to that organic fertilizers enhance soil aeration and increase nutrient hold capacity and offer good environmental conditions for the root system. These favorable conditions create better nutrients absorption and enhance the growth, which reflect improving of vegetative growth, photosynthetic activity, dry matter accumulation and consequently higher yield and good properties of pods. Concerning organic treatments, using vermicampot produced the highest yield and properties of pods compared to compost only or combined with vermicompost. Vermicompost superiority on compost might be due to that conventional compost is higher in ammonium content, while the vermicompost is higher in nitrate content, which is the more available form of nitrogen for plant absorption. In addition, vermicompost releases nutrients during short time compared to conventional compost. This was verified by Atiyeh, et al. (2000), Singh \& Chauhan (2009), Manivannan et al. (2009), Mupondi et al. (2010) and Metkari et al. (2011).
The effect of treatments on some compositions of green bean pods show in Table 7. Data reveled that there were no statistical differences on all pod compositions except protein and nitrate contains in bean pods. All treatments of compost and vermicompost without mineral fertilizers decreased protein percent in pods. The low protein content of the pods may be due to the low amount of nitrogen available for plant absorption from organic fertilizers, where nitrogen is the basis of amino acids synthesis that are essential components of protein. This was supported by the findings of Metkari et al. (2011), Shehata et al. (2011) on snap bean and Khaim et al. (2013) on soybean. As well as all treatments of compost and vermicompost with or without mineral fertilizers, decreased nitrate content in bean pods. The lowest values of nitrate content in pods obtained when plants were treated organic fertilizers without mineral fertilizers. This may be due to the release of nitrate from mineral fertilizers is fast while, in organic fertilizers, it is slow. These findings are harmony with those obtained by Stancheva et al. (2004) on garden beans, Mahmoud et al. (2009) and Abou-El-Hassan et al. (2014) on cucumber.

TABLE 7. Effect of treatments on compositions of green bean pods during 2016 and 2017 seasons.

\begin{tabular}{|c|c|c|c|c|c|c|c|c|c|c|}
\hline Treatments & \multicolumn{10}{|c|}{ First season } \\
\hline $100 \% \mathrm{C}$ & 5.033 & $\mathrm{a}$ & 1.106 & a & 1.558 & $\mathrm{c}$ & 7.307 & $\mathrm{a}$ & 189 & $\mathrm{f}$ \\
\hline $100 \% \mathrm{~V}$ & 5.100 & a & 1.103 & a & 1.580 & $\mathrm{bc}$ & 7.413 & $\mathrm{a}$ & 224 & de \\
\hline $50 \% \mathrm{C}+50 \% \mathrm{~V}$ & 5.033 & a & 1.150 & a & 1.561 & $\mathrm{c}$ & 7.473 & $\mathrm{a}$ & 206 & ef \\
\hline $50 \% \mathrm{MF}+50 \% \mathrm{~V}$ & 5.067 & $\mathrm{a}$ & 1.175 & $\mathrm{a}$ & 1.677 & $\mathrm{a}$ & 7.453 & $\mathrm{a}$ & 272 & $\mathrm{~b}$ \\
\hline \multirow[t]{2}{*}{$50 \% \mathrm{MF}+25 \% \mathrm{C}+25 \% \mathrm{~V}$} & 5.000 & a & 1.170 & a & 1.665 & $\mathrm{ab}$ & 7.427 & a & 245 & $\mathrm{c}$ \\
\hline & \multicolumn{10}{|c|}{ Second season } \\
\hline $100 \% \mathrm{MF}$ & 5.320 & $\mathrm{a}$ & 1.255 & a & 1.661 & $\mathrm{a}$ & 8.103 & $\mathrm{a}$ & 507 & $\mathrm{a}$ \\
\hline $100 \% \mathrm{C}$ & 5.193 & $\mathrm{a}$ & 1.224 & a & 1.526 & $\mathrm{~b}$ & 7.870 & $\mathrm{a}$ & 245 & $\mathrm{e}$ \\
\hline $50 \% \mathrm{MF}+50 \% \mathrm{~V}$ & 5.287 & $\mathrm{a}$ & 1.237 & $\mathrm{a}$ & 1.650 & $\mathrm{a}$ & 8.117 & $\mathrm{a}$ & 340 & $\mathrm{~b}$ \\
\hline $50 \% \mathrm{MF}+25 \% \mathrm{C}+25 \% \mathrm{~V}$ & 5.273 & a & 1.240 & a & 1.624 & $\mathrm{a}$ & 7.989 & $\mathrm{a}$ & 309 & $\mathrm{c}$ \\
\hline
\end{tabular}

Means followed in same column by similar letters are not statistically different at 0.05 level according to Tukey test.

$\mathrm{DM}=$ dry matter $\quad \mathrm{MF}=$ mineral fertilizer

$\mathrm{C}=$ compost

$\mathrm{V}=$ vermicompost

\section{Conclusion}

It could be concluded that the using compost and vermicompost as substitutes partial of mineral fertilizers producing good yield and healthy of green beans.

Egypt. J. Hort. Vol. 44, No.2 (2017)
Acknowledgements: We thank Central Lab of Organic Agriculture and Department of Protected Agriculture Research, Agriculture Research Center for technical assistance and provide a place to conduct the experiment. We thank also Arid Land Agricultural Research Center, Faculty of Agriculture, Ain Shams University for kindly 
of all chemical analyses.

Funding statements: The authors received no external funding for this study

Conflicts of interest: The authors have no conflicts of interest to declare

\section{References}

Abd El-Hamied, A. (2001) Evaluation of nitrite, nitrate and nitrosamine compounds in Upper Egypt vegetables. Alex. Sci. Exch. J., 22 (3), 323-332.

Abdel-Mawgoud, A.M.R. (2006) Growth, Yield and quality of green bean (Phaseolus Vulgaris) in response to irrigation and compost applications. Journal of Applied Sciences Research, 2 (7), 443-450.

Abduli, M.A., Amiri, L., Madadian, E., Gitipour S. and Sedighian, S. (2013) Efficiency of vermicompost on quantitative and qualitative growth of tomato plants.Int. J. Environ. Res., 7 (2), 467-472.

Abou-El-Hassan S., Abdrabbo M.A.A. and Desoky, A.H. (2014) Enhancing organic production of cucumber by using plant growth promoting rhizobacteria and compost tea under sandy soil condition. Research Journal of Agriculture and Biological Sciences, 10 (2), 162-169.

Albiach, R., Canet, R.R., Pomares, F. and Ingelmo, F. (2000) Microbial biomass content and enzymatic activities after the application of organic amendments to a horticultural soil. Bioresource Technology, 75, 43-48.

Alhrout, H.H., Aldal'in, H.K.H., Haddad, M.A., BaniHani, N.M. and Al-Dalein, S.Y. (2016) The impact of organic and inorganic fertilizer on yield and yield components of common bean (Phaseolus vulgaris). Advances in Environmental Biology, 10 (9), 8-13.

Al-Moshileh, A.M., Al-Redhaiman, K.N. and ElShinawy, M.Z. (2004) The effect of nitrogen sources on yield and nitrate accumulation in lettuce and cabbage plants. Egypt. J. Appl. Sci., 19, 646-654.

AOAC (2005) Official Methods of Analysis,

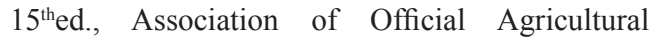
Chemists. $12^{\text {the }}$., Washengton, D.C., USA.

Arancon, N.Q., Edwards, C.A., Babenko, A., Cannon, J., Galvis, P. and Metzger, J.D. (2008) Influences of vermicomposts, produced by earthworms and microorganisms from cattle manure, food waste and paper waste, on the germination, growth and flowering of petunias in the greenhouse. Applied Soil Ecology, 39, 91-99.
Atiyeh, R.M., Subler, S., Edwards, C.A., Bachman, G., Metzger, J.D. and Shuster, W. (2000) Effects of vermicomposts and composts on plant growth in horticultural container media and soil. Pedobiologia, 44, 579-590.

Baziramakenga, R. and Simard, R.R.S. (2001) Effect of deinking paper sludge compost on nutrient uptake and yields of snap bean and potatoes grown in rotation. Compost Sci. Util., 9 (2), 115-126.

Cespedes Leon, M.C., Stone, A. and Dick, R.P. (2006) Organic soil amendments, impacts on snap bean common root rot and soil quality. Applied Soil Ecology, 31 (3), 199-210.

Chapman, H.D. and Pratt, P.F. (1961) Methods of Analysis for Soil, Plant and Water, Division of Agric. Sci., Calif. Univ.

Cottenie, A., Verloo, M., Kiekers, L., Velghe, G. and Camrbynek, R. (1982) Chemical Analysis of Plants and Soils. Hand Book, 1-63, Ghent, Belgium.

Deshmukh, K.K., Khatik, S.K., and Dubey, D.P. (2005) Effect of integrated use of inorganic, organic and biofertilizer on production nutrient availability and economic feasibility of soybean grown on soil of Kaymore plateau and Satpura hills. J. Soils and Crops, 15 (1), 21-25.

Edwards, C.A.and Bater, J.E. (1992) The use of earthworms in environmental management. Soil Biology and Biochemistry, 24 (12), 1683-1689.

FAO (1989) Soil and Plant Analysis.Soils Bulletin $38 / 2,250 \mathrm{P}$.

Fernandez-Luqueno, F., Reyes-Varela, V., MartinezSuarez, C., Salomon-Hernandez, G., YanezMeneses, J., Ceballos-Ramirez, J.M. and Dendooven, L. (2010) Effect of different nitrogen sources on plant characteristics and yield of common bean (Phaseolus vulgaris L.). Bioresource Technology, 101, 396-403.

Giusquiani, P.L., Pagliai, M., Gigliotti, G., Businelli, D.andBenetti, A. (1995) Urban waste compost, effects on physical, chemical and biochemical soil properties. J. Environ. Quality, 24, 175-182.

Hernandez, A., Castillo, H., Ojeda, D., Arras, A., Lopez, J. and Sanchez, E. (2010) Effect of vermicompost and compost on lettuce production. Chilean $J$. Agric. Res., 70 (4), 583-589.

Inbar, Y., Hadar, Y. and Chen, Y. (1993) Recycling of cattle manure, The composting process and characterization of maturity. J. Environ. Quality, 22, 857-863. 
Insam, H. and de Bertoldi, M. (2007) Microbiology of the composting process. In L. F. Diaz, M. de Bertoldi, W. Bidlingmaier and E. Stentiford (Eds.), Waste Management Series, 8, 25-48. Amsterdam, The Netherlands, Elsevier.

Kadam, D. and Pathade, G. (2014) Effect of tendu (Diospyros melanoxylon Rox B.) leaf vermicompost on growth and yield of French bean (Phaseolus vulgaris L.). Int. J. Recycl Org. Waste Agricult., 3 (44), 1-7.

Khaim, S., Chowdhury, M.A.H. and Saha, B.K. (2013) Organic and inorganic fertilization on the yield and quality of soybean. J. Bangladesh Agril. Univ., 11 (1), 23-28.

Kowalchuk, G., Naoumenko, Z., Derikx, P., Felske, A., Stephen, J. and Arkhipchenko, I. (1999) Molecular analysis of ammonia-oxidizing bacteria of the $\beta$ subdivision of the class proteobacteria in compost and composted materials.Applied Environment Microbiology, 65 (2), 396-403.

Mahmoud, E.K., Abd EL-Kader, N., Robin, P., AkkalCorfini, N. and Abd El-Rahman, L. (2009) Effects of different organic and inorganic fertilizers on cucumber yield and some soil properties. World J. Agric. Sci., 5 (4), 408-414.

Manivannan, S., Balamurugan, M., Parthasarathi, K., Gunasekaran, G. and Ranganathan, L.S. (2009) Effect of vermicompost on soil fertility and crop productivity-bean (Phaseolus vulgaris). J. Environ. Biol., 30 (2), 275-281.

Martens, D.A. (2000) Management and crop residue influence soil aggregate stability. J. Environ. Quality, 29, 723-727.

Mavaddati, S., Kianmehr, M.H., Allahdadi, I. and Chegini, G.R. (2010) Preparation of pellets by urban waste compost, Int. J. Environ. Res., 4 (4), 665-672.

Metkari, P.M. and Dhok, S.P. (2011) Effect of organic and inorganic fertilization on soil fertility and productivity of french bean in Vertisol. Asian J. Soil Sci., 6 (1), 80-84.

Ministry of Agriculture and Land Reclamation (2013) Soils, Water and Environment Research Institute, Agricultural Research Centre.

Ministry of Agriculture and Land Reclamation (EAS), Economic Affairs Sector (2015) The Indicators Agriculture Statistics.
Mitova, I. and Stancheva, I. (2013) Effect of fertilizer source on the nutrients biological uptake with garden beans production. Bulgarian Journal of Agricultural Science, 19 (5), 946-950.

Mupondi, L.T., Mnkeni, P.N.S. and Muchaonyerwa, P. (2010) Effectiveness of combined thermophilic composting and vermicomposting on biodegradation and sanitization of mixtures of dairy manure and waste paper. African Journal of Biotechnology, 9, 4754-4763.

Parakash, R. and Prasad, M. (2000) Effect of nitrogen, chlormequat chloride and farmyard manure applied to cotton (Gossypiumhirsutum) and their residual effect on succeeding wheat (Triticumaestivum) crop.Indian J. Agron., 45 (2), 263-268.

Sharma, S., Upadhyay, R.G. and Sharma, C.R. (2003) Response of various levels of nitrogen and phosphorus application on growth, physiological parameters and yield of mungbean under rainfed and mid hill conditions of Himachal Pradesh. Indian Journal of Agricultural Research, 37 (1), 52-55.

Shehata, S.A. and El-Helaly, M.A. (2010) Effect of compost, humic acid and amino acid on yield of snap beans.J. Horti. Sci. \& Ornamental Plants, 2 (2), 107-110.

Shehata, S.A., Ahmed, Y.M., Shalaby, E.A. and Darwish, O.S. (2011) Influence of compost rates and application time on growth, yield and chemical composition of snap bean (Phaseolus vulgaris L). Aust. J. Basic \& Appl. Sci., 5 (9), 530-536.

Singh, B.K., Pathak, K.A., Verma, A.K., Verma, V.K. and Deka, B.C. (2011) Effects of vermicompost, fertilizer and mulch on plant growth, nodulation and pod yield of French bean (Phaseolus vulgaris L.). Vegetable Crops Research Bulletin, 74, 153165.

Singh, N.I. and Chauhan, J.S. (2009) Response of french bean (Phaseolus Vulgaris L.) to organic manures and inorganic fertilizer on growth and yield parameters under irrigated condition. Nature and Science, 7 (5), 52-54.

Snedecor, G.W. and Cochran, W.G. (1980) Statistical methods.Sixth Edition, Iowa state university press, Ames., Iowa, U.S.A.

Stancheva, I., Mitovab, I. and Petkovab, Z. (2004) Effects of different nitrogen fertilizer sources on the yield, nitrate content and other physiological parameters in garden beans.Environmental and Experimental Botany, 52 (3), 277-282.

Egypt. J. Hort. Vol. 44, No.2 (2017) 
Wells, A.T., Chan, K.Y. and Cornish, P.S. (2000)

Comparison of conventional and alternative vegetable farming systems on the properties of a

(Received 05/09/2017; yellow earth in New South Wales. Agri. Eco. and accepted 14/12/2017)

Environ., 80 (1-2), 47-60.

\section{إستخدام الكمبوست والفيرميكمبوست كبدائل للاسمدة المعدنية لانتاج الفاصوليا الخضراء

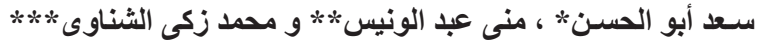

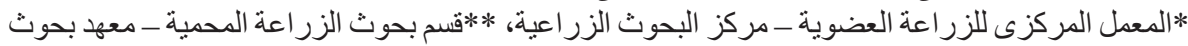 البساتين - مركز البحوث الزر اعية و***قنم البساتين- كلية الزر اعة - جامعة عين شمس - القاهرة - مصر.}

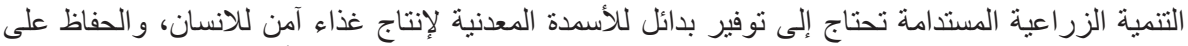

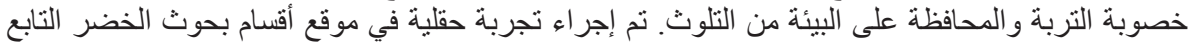

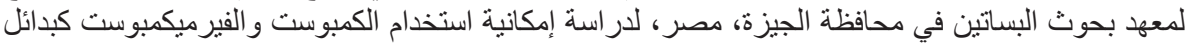

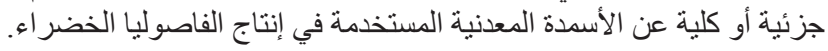

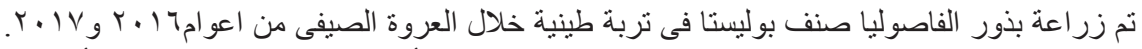

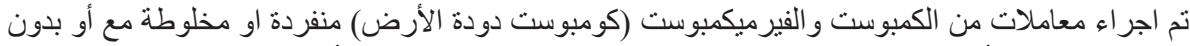

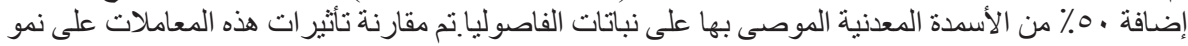
ومحصول الفاصوليا بالمعدل الكامل الموصى به به من الأسمدة المعدنية.

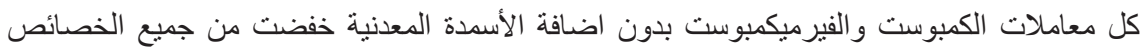

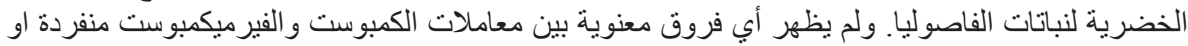

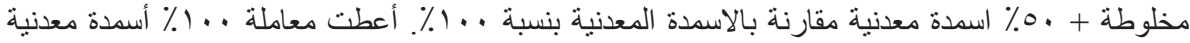

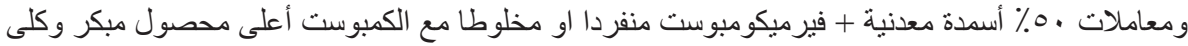

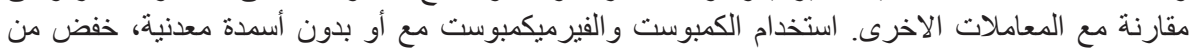

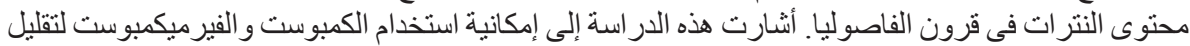

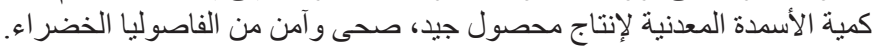

